\title{
INFLUENCE OF L-CARNITINE DAILY SUPPLEMENT ON QUALITATIVE AND QUANTITATIVE EJACULATE INDICATORS IN BOARS DURING THE SUMMER PERIOD
}

\author{
Magdalena Přibilová ${ }^{1}$, Pavel Horkýํ, Lenka Urbánková ${ }^{1}$,

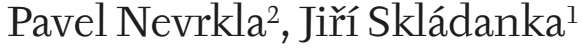

\footnotetext{
${ }^{1} 1$ Department of Animal Nutrition and Forage Production, Faculty of Agrisciences, Mendel University in Brno, Zemedelska 1, 61300 Brno, Czech Republic

${ }^{2}$ Department of Animal Breeding, Faculty of Agrisciences, Mendel University in Brno, Zemedelska 1, 61300 Brno, Czech Republic
}

To cite this article: PŘIBILOVÁ MAGDALENA, HORKÝ PAVEL, URBÁNKOVÁ LENKA, NEVRKLA PAVEL, SKLÁDANKA JIŘÍ. 2018. Influence of L-Carnitine Daily Supplement on Qualitative and Quantitative Ejaculate Indicators in Boars During the Summer Period. Acta Universitatis Agriculturae et Silviculturae Mendelianae Brunensis, 66(5): 1199-1206.

To link to this article: https://doi.org/10.11118/actaun201866051199

\begin{abstract}
The purpose of the project was to determine impact of added L-carnitine in feed ration on quality of Duroc boar ejaculate during the summer period (June-September). Temperature in the stable achieved up to $29.9{ }^{\circ} \mathrm{C}$. For the experiment was chosen 24 Duroc boars. Boars were divided into 2 groups: The control group of boars $(n=12)$ was fed by the basic feed mixture only. The experimental group of boars $(\mathrm{n}=12$ ) was supplemented by $500 \mathrm{mg}$ of L-carnitine $/ \mathrm{kg}$ of the feed ration. Ejaculate was collected once a week. Monitored parameters were: volume of ejaculate, concentration of sperm, total sperm count, motility of sperm and percentage of morphologically abnormal sperm. L-carnitine concentration in the ejaculate was monitored as well.

Results of the experiment show that supplementation of $500 \mathrm{~g}$ of L-carnitine into boar ration had a positive impact on sperm motility, significant difference between the boar groups by $8.54 \%$ $(\mathrm{P}<0.05)$ and on decreased morphologically abnormal sperm, significant difference between groups by $12.6 \%(\mathrm{P}<0.05)$, and also significant difference in experimental group during the monitoring by $4.06 \%(\mathrm{P}<0.05)$. After biochemical analysis have been found a statistically significant increase in concentration of L-carnitine in the ejaculate of the experimental group (up to $21.1 \mu \mathrm{g} / \mathrm{ml}$ ) and a statistically significant difference between groups $(22.0 \mu \mathrm{g} / \mathrm{ml}),(\mathrm{P}<0.05)$.
\end{abstract}

Keywords: L-carnitine, ejaculate, antioxidants, boar

\section{INTRODUCTION}

L-carnitine is the natural, vitaminous amino acid synthesized from lysine and methionine (Vaz and Wanders, 2002). L-carnitine is synthesized in the liver, kidney and brain (Cibulka, 2005). Animal organism is able to create it partially by itself, but its whole need is covered mainly by nutrition (Jeulin et al., 1994). L-carnitine is a very important within metabolism of lipids. It brings long-chain fatty acids into the mitochondria for beta-oxidation, thus producing the energy (ATP) necessary for proper sperm functioning 
(Hoppel, 2003; Horký et al., 2012). It is also very important for detoxification of the organism, because it eliminates mitochondrial acetyl-CoA, which overdose is toxic for the organism (Arrigoni-Martelli and Caso, 2001). It also plays an important role in the antioxidant chain, as it avoids oxidative damage of the cell membranes, which is caused by polyunsaturated fatty acids peroxidation, the integral part of the membrane phospholipids (Kalaiselvi and Panneerselvam, 1998; Horký, 2014). Oxidative damage to the cell membranes occurs in stressful situations, when a large amount of free oxygen radicals is produced (Horký et al, 2015). Exposure of male germ line to oxidative stress leads to sperm damage, loss of integrity of their cores and mitochondria (Aitken et al., 2003; Horký et al., 2016). According to Maya-Soriano et al. (2013), free radicals affect especially mitochondria that provide energy and motility for the sperm. The main cause of infertility is considered exactly the oxidative stress (Aitken, 1994). In the literature can be found the information about positive effect of L-carnitine on spermatogenesis (Jacyno et al., 2007). In humans was monitored the positive effect of daily addition of L-carnitine on increase of sperm concentration and motility (Vitali et al., 1995).

L-carnitine is absorbed during sperm maturation in the epididymis (Agarwal and Sait, 2004). The epididymal plasma concentration of L-carnitine of boars varies in the range of 200-300 nmol/mg of protein. From epididymis it is transported by passive diffusion into the sperm (Jeulin et al., 1987). The sperm entering the epididymis are immobile and concentration of free L-carnitine is very low. While passing through the epididymis (1-10 days), they accumulate a high concentration of L-carnitine from the epididymal plasma, thus conferring motility upon the flagellum (Jeulin et al., 1994).
The mammal testicles are seated outside the body cavity, which causes that the temperature in testicles by a few degrees lower than the body core temperature, usually by the $2.5^{\circ} \mathrm{C}$. This temperature must be sustained for optimal fertility of the boars for proper progress of spermatogenesis, storage of sperm and for minimization of DNA mutations in the gametes. If the testicle tissue is exposed to a higher temperature, sperm production is decreased, motility reduced and number of morphologically abnormal sperm in the ejaculate increased (Hansen, 2009; Gadd, 2011). It is stated in general that critical value for occurrence of the heat stress is $25^{\circ} \mathrm{C}$ in boars (Hájek et al., 1992). The sperm changes do not occur immediately after the duration of heat stress, but symptoms of the oxidative stress usually appear after 7-14 days, and reclaim of proper quality of ejaculate is after 5-8 weeks. At least 45 days must elapse to resume normal sperm ejaculation, because 35 days lasts the sperm production and 10 days lasts their passage through the epididymis (Hansen, 2009, Smital, 2001). Positive effect of L-carnitine addition can be observed as early as after one week addition to the feed ration (Jacyno et al., 2007).

The purpose of the project was to verify effect of L-carnitine on the quality of boar ejaculate during the summer period.

\section{MATERIALS AND METHODS}

The experiment took place in the boar station of insemination in Velké Meziříčí (N 49²3.46667', E 1552.70135'; Czech Republic). The monitored periaod lasted for 120 days (June-September). 24 boars of the Duroc breed, weighing $255 \pm 20 \mathrm{~kg}$ and $2 \pm 0.3$ years old, were selected for the experiment. The boars were housed individually in pens

I: Composition offeed mixture.

\begin{tabular}{|c|c|}
\hline Component & $\%$ of feed mixture \\
\hline Wheat grain & 20.36 \\
\hline Oat grain & 20.00 \\
\hline Soybean meal & 14.50 \\
\hline BergaFat (palm oil) & 2.10 \\
\hline Calcium carbonate & 1.50 \\
\hline Monodicalciumphosphate & 1.20 \\
\hline Mineral vitamin premix for boars $0.5 \%$ & 0.50 \\
\hline L-Lysine HCl & 0.14 \\
\hline L-Threonine & 0.09 \\
\hline Methionine DL & 0.06 \\
\hline
\end{tabular}


II: Composition of premix (0.5\%)

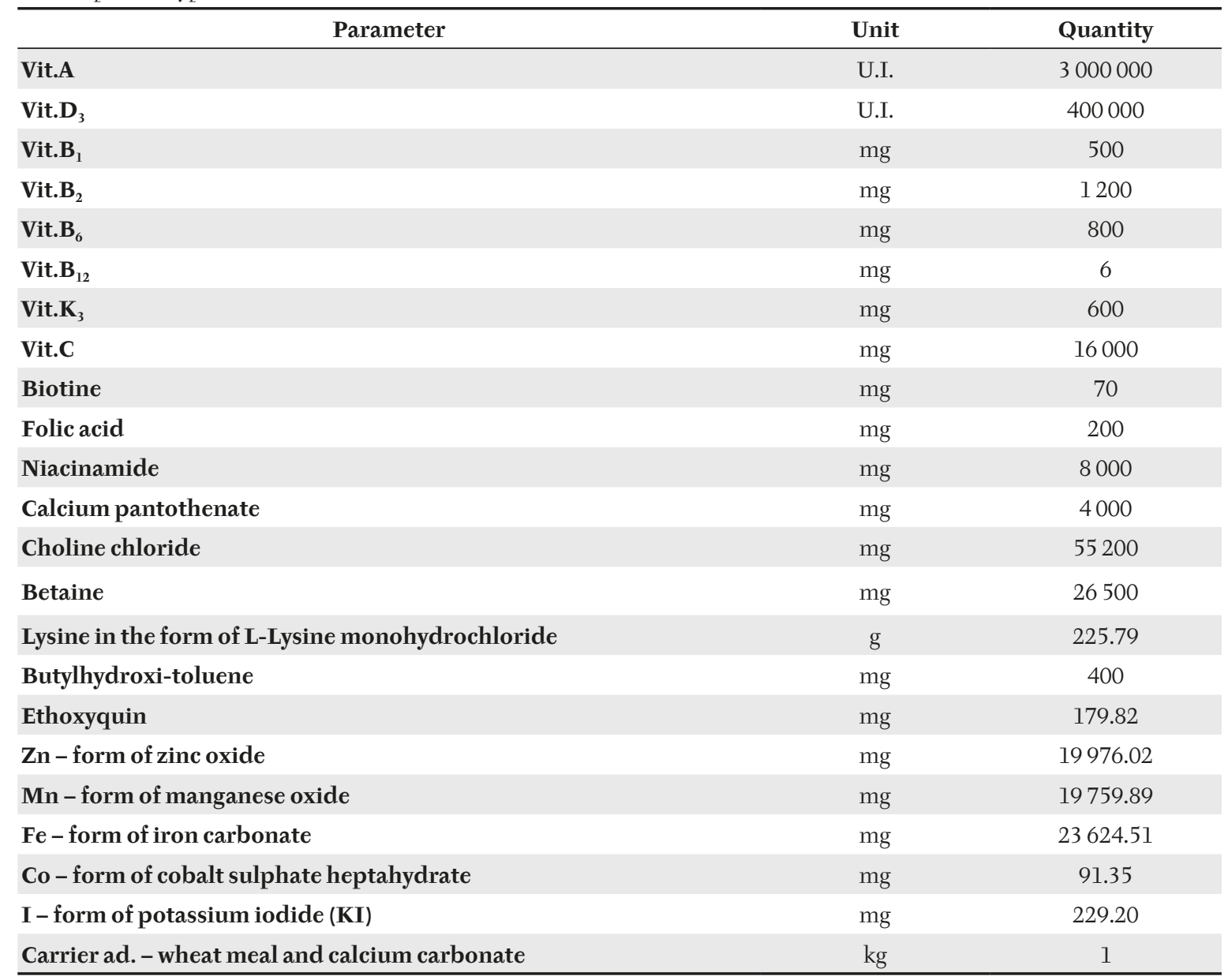

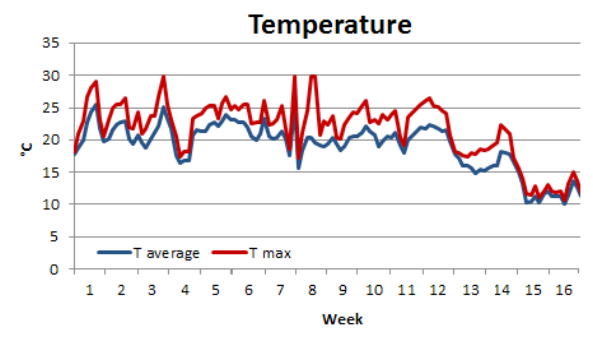

1: Average and maximum temperature $(\mathrm{T})$ in the stable during the experiment.

$(2.5 \times 2.5 \mathrm{~m})$. The feed mixture (MEp $12.6 \mathrm{MJ} / \mathrm{kg})$ was fed at a dose of $3.3 \mathrm{~kg}$ (see Tab. I); the boars had ad libitum access to water. The two equal groups of boars established, where the control group $(\mathrm{n}=12)$ was fed by only the basic feed mixture and the experimental group $(n=12)$ was fed by the basic feed with supplementation of $500 \mathrm{mg}$ of L-carnitine/kg of the feed ration. Feed mixture was homogenized for to provide a certain amount of L-carnitine (analysed by Decree No. 415/2009 Coll. On the determination of the requirements for sampling and the method of publication of methods of laboratory testing of products for feeding).

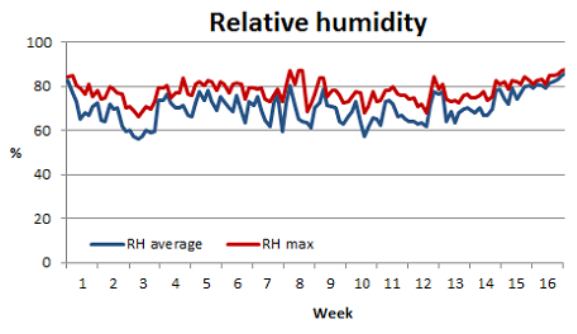

2: Average and maximum relative humidity $(R H)$ in the stable during the experiment.

In the stable there is no cooling system, only natural air circulation is used there. The temperature $\left({ }^{\circ} \mathrm{C}\right)$ and the relative humidity (\%) in the stable was measured at hourly intervals at the animal level ( $1 \mathrm{~m}$ above ground level) by the Datalogger (Voltcraft DL-121TH, Germany). From the measured values the average and the maximum daily temperature and the relative humidity were determined and the values were plotted: Fig. 1-Temperature and Fig. 2-Relative humidity.

The ejaculate was taken once a week by using a jump phantom and hand gloved technique 
into a pre-warmed sterilised plastic collector. Methodology of ejaculate analysis was determined by Lovercamp et al. (2013).

\section{Analysis of ejaculate:}

Determination of ejaculate volume - each ejaculate was weight with $1 \mathrm{~g}$ to $1 \mathrm{ml}$ conversion.

Determination of sperm concentration - determined by using a self-calibrating photometer (SpermaCueTM, Minitube of America, Verona, WI).

Determination of sperm motility - determined by using the Sperm Vision ${ }^{\text {Tw }}$ software (Minitube of America, Verona, WI) with digital camera connection to a contrast microscope (Olympus microscope IX 71 S8F-3; Tokyo, Japan). Prior to analysing, $500 \mu \mathrm{l}$ of each sample was diluted with $500 \mu \mathrm{l}$ of Androhep diluent and incubated for 30 minutes at $37^{\circ} \mathrm{C}$.

Determination of morphologically abnormal sperm - A $50 \mu \mathrm{l}$ aliquot from each sample was fixed by adding $5 \mu \mathrm{l}$ of $10 \%$ buffered formalin. $5 \mu \mathrm{l}$ of this sample was dropped on slide and mounted with a coverslip and incubated for $30 \mathrm{~min}$ (in $25^{\circ} \mathrm{C}$ and $100 \%$ humidity and) to immobilize the spermatozoa. Coloration of samples was saturated in water solution of congo-red and then in $0.5 \%$ aqueous solution of crystal violet. Sperm morphology vas evaluated by using a phase contrast microscope (Zeiss, Germany) with an oil immersion lens at a magnification of $1500 \times$. The most frequently occurring defects were protoplasmic drops and deformation of the sperm flagella. Subjective assessment was performed by a single qualified person.

Determination of the total sperm count - determined by calculation (sperm concentration $\times$ ejaculate volume).

\section{Biochemical analysis-determination of free L-carnitine in ejaculate}

Biochemical analysis were performed according to the methodology by Čeřovský et al. (2009). One sample was taken once a month from all boars for the biochemical analysis and frozen for later analyzes. $250 \mu \mathrm{l}$ of $\mathrm{pH}=7$ phosphate buffer was added to $250 \mu \mathrm{l}$ of defrosted boar sperm and the solution was poured over by $2 \mathrm{ml}$ of liquid nitrogen. The mixture was homogenized for 2 minutes at $3000 \mathrm{rpm}$ in ice. $1 \mathrm{ml}$ of phosphate buffer was added and the mixture was shaken for 30 minutes at $4{ }^{\circ} \mathrm{C}$ and centrifuged at $6000 \mathrm{rpm}$ for 15 minutes afterwards. After centrifugation the supernatant was removed, which $500 \mu \mathrm{l}$ of $10 \%$ TFA was added to. The sample was re-centrifuged and the supernatant taken for analysis using amino acid analyzer (AAA 400, Ingos, Czech Republic).

\section{Statistics}

The statistical analysis was done by using STATISTICA.CZ version 10.0 (Czech Republic). The results were stated as the mean \pm standard variance. Statistical significance was observed between the groups (the first sampling was taken as a control one) using ANOVA and Scheffe's test - the two-factor analysis (the first factor was the animal group, the second one - the sampling factor) for parameters of L-carnitine ejaculate volume, sperm concentration and motility, percentage of morphologically abnormal sperm. The difference $(\mathrm{P}<0.05)$ was considered as significant.

The experiment was carried out in accordance with the Law no. 246/1992 Sb. on the protection of animals against cruelty and approved by ethic committee of Mendel University in Brno.

\section{RESULTS}

The volume of ejaculate, concentration of sperm and sperm motility, percentage of morphologically abnormal sperm, total produced sperm count and L-carnitine concentration in the ejaculate were selected as the markers related directly with addition of the dietary L-carnitine.

Fig. 3A shows impact of L-carnitine addition on the boar ejaculate volume and its comparison with the control group. The results show that addition of $500 \mathrm{mg}$ of L-carnitine had statistically significant effect on the ejaculate volume only in $13^{\text {th }}$ week of experiment, where was significant difference between groups by $78,3 \mathrm{ml}(\mathrm{P}<0.05)$. There was statistical difference also between groups in $2^{\text {nd }}$ week (by $59,17 \mathrm{ml})(\mathrm{P}<0.05)$ and in $10^{\text {th }}$ (by $51.7 \mathrm{ml}$ ) and $11^{\text {th }}$ week (by $\left.51 \mathrm{ml}\right)(\mathrm{P}<0.05)$. Significant increase in control group was observed between $13^{\text {th }}$ and $14^{\text {th }}$ week (by $75 \mathrm{ml})(\mathrm{P}<0.05)$.

Fig. 3B shows concentration of sperm. In both the groups the sperm concentration varied, depending on the ejaculate volume. There was statistically significant decrease in $14^{\text {th }}$ week $\left(350 \times 10^{6} / \mathrm{ml}\right)$ in the experimental group, according to increase of volume of ejaculate in this week $(\mathrm{P}<0.05)$. Statistically significant increase of concentration of sperm was observed in $13^{\text {th }}$ week $\left(835 \times 10^{6} / \mathrm{ml}\right)$ in control group, according to decrease of volume of ejaculate $(\mathrm{P}<0.05)$. Differences between groups were statistically significant in $13^{\text {th }}$ (by $245 \times 10^{6} / \mathrm{ml}$ ) and $14^{\text {th }}$ (by $200 \times 10^{6} / \mathrm{ml}$ ) week $(\mathrm{P}<0.05)$.

Fig. 4A shows results of the total sperm count. Statistically significant differences between groups were observed in $2^{\text {nd }}\left(\right.$ by $\left.35 \times 10^{9}\right), 6^{\text {th }}\left(\right.$ by $\left.6.5 \times 10^{9}\right)$ and $15^{\text {th }}$ week (by $\left.49.4 \times 10^{9}\right)(\mathrm{P}<0.05)$. Statistically significant increase of total rate of sperm was in experimental group between $14^{\text {th }}$ and $15^{\text {th }}$ week (by $\left.67.8 \times 10^{9}\right)(\mathrm{P}<0.05)$, followed by the significant difference by $61.2 \times 10^{9}$ between $15^{\text {th }}$ and $16^{\text {th }}$ week $(P<0.05)$. These fluctuations were occurred depending on changes in volume of ejaculate and concentration of sperm.

In Fig. 4B, assessment of the morphologically abnormal sperm, the statistically significant difference between the monitored groups was established from $6^{\text {th }}$ to $12^{\text {th }}$ week (in average by $10.59 \%)(\mathrm{P}<0.05)$ and in $14^{\text {th }}$ week by $9 \%(\mathrm{P}<0.05)$, In this period $\left(6^{\text {th }}-12^{\text {th }}\right.$ week $)$ daily maximum 

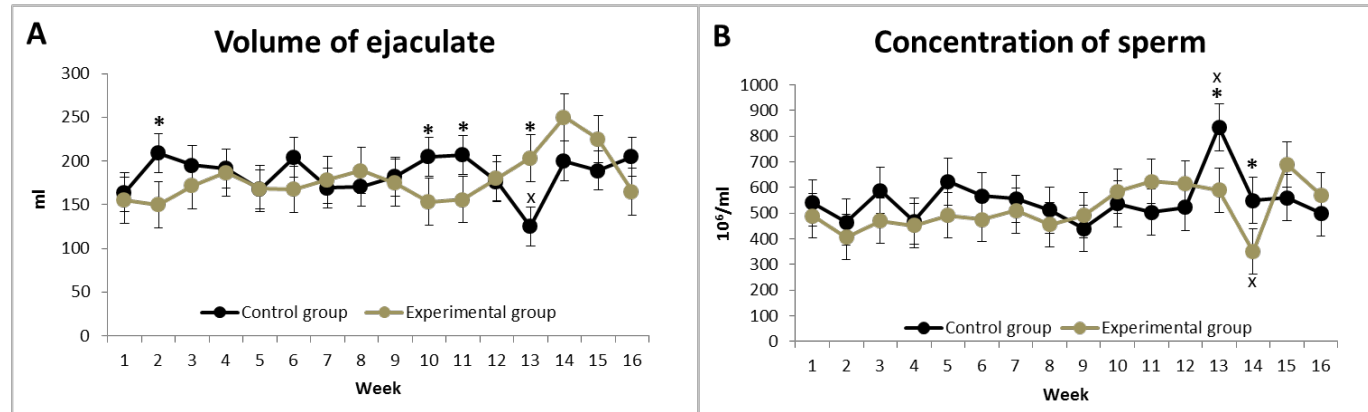

3: Indicators of quality of ejaculate; A: Volume of ejaculate, B: Concentration of sperm.
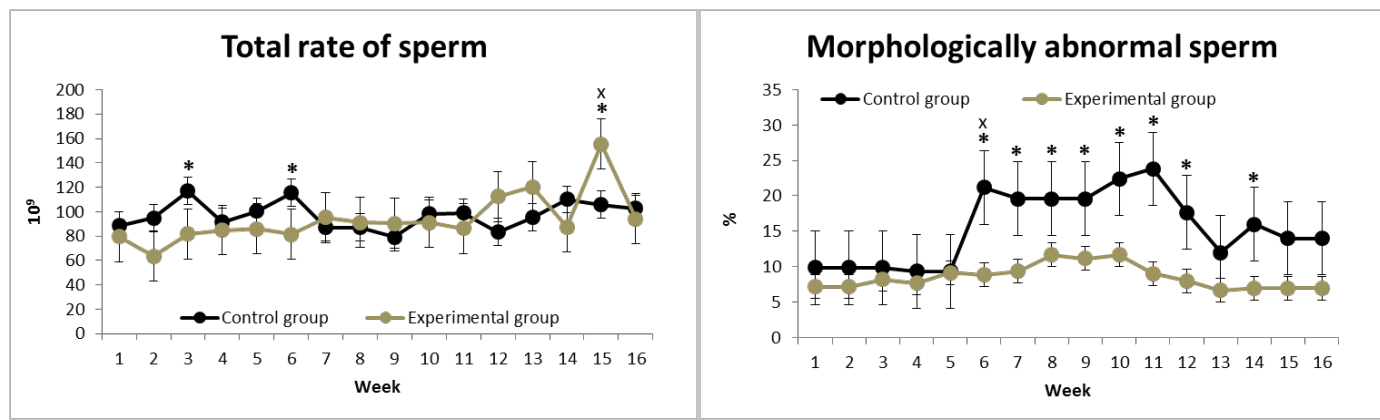

4: Indicators of quality of ejaculate; A: Total rate of sperm in ejaculate, B: morphologically abnormal sperm
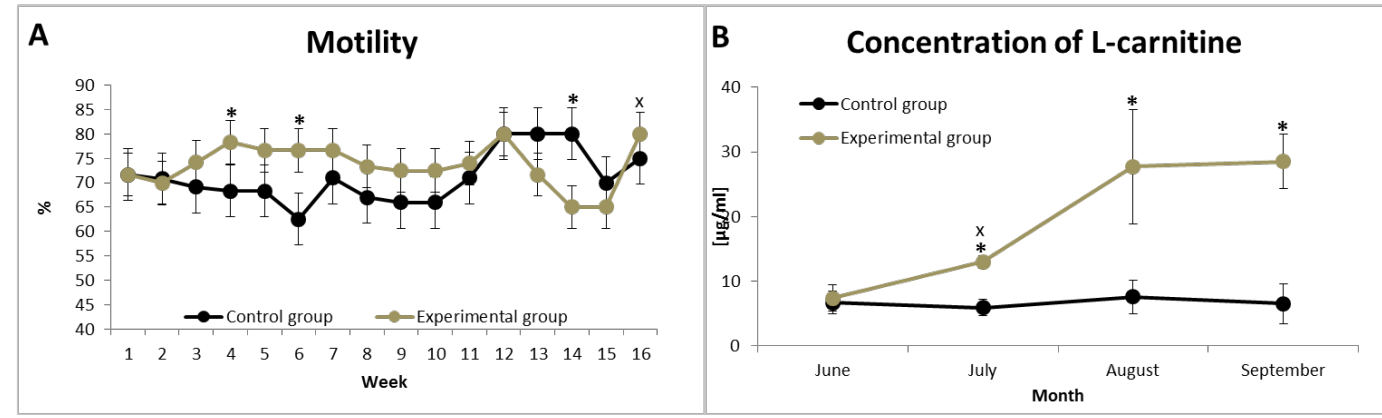

5: Indicators of quality of ejaculate; A: Motility of sperm, B: Concentration of L-carnitine in ejaculate

temperature reached a peak of $30^{\circ} \mathrm{C}$, so there it can be seen positive effect of L-carnitine supplementation on protection of sperm cells during the heat stress. Statisticaly significant increase was also in control group between $5^{\text {th }}$ and $6^{\text {th }}$ week (by $\left.11.83 \%\right)(\mathrm{P}<0.05)$,

Fig. 5A: The statistically significant differences in sperm motility between then monitored groups were in $4^{\text {th }}$ week (by 10\%), $6^{\text {th }}$ week (by $14.2 \%$ ) and $14^{\text {th }}$ week (by $\left.15 \%\right)(\mathrm{P}<0.05)$. Statistically significant increase of motility was observed between $15^{\text {th }}$ and $16^{\text {th }}$ week in experimental group (by 15.1\%) $(\mathrm{P}<0.05)$.

Fig. 5B: After biochemical analysis of L-carnitine content, the statistically significant difference in increase of free L-carnitine concentration in the ejaculate was established. The statistically significant difference between the monitored groups was as follows: in July (days $30-60$ ) by 7.05 $\mu \mathrm{g} / \mathrm{ml}(\mathrm{P}<0.05)$, in August (days 60 - 90) by 20.19 $\mu \mathrm{g} / \mathrm{ml}(\mathrm{P}<0.05)$ and in September (days $90-120)$ by $21.96 \mu \mathrm{g} / \mathrm{ml}(\mathrm{P}<0.05)$.

\section{DISCUSSION}

We have not observed positive effect of L-carnitine addition on ejaculate volume. In weeks 2, 10, 11 and 13 differences between groups were statistically significant. Yeste et al. (2010) states, that addition of L-carnitine has no significant effect on volume of ejaculate in boars.

Kunavongkrit et al. (2005) report that the highest concentration of sperm was established in autumn and winter and the lowest concentration in spring and summer periods. It has been proved that the rising volume of ejaculate tends to reduction of sperm concentration (Knecht et al., 2014). It is confirmed by our results-in week 13 and 14 there was significant difference between groups (due to the variation of volume of ejaculate). Increase in volume of ejaculate and tatal rate of sperm has a significant influence for insemination - the number of produced insemination doses (Jacyno et al., 2007). The boars supplemented with $500 \mathrm{mg}$ of L-carnitine 
was added to daily diet, produced a higher number of insemination doses from the one ejaculate, namely by one dose/ejaculate (Baumgartner, 1998). On the contrary, Čeřovský et al. (2009) did not report any significant effect of L-carnitine addition on quality of boar ejaculate.

L-carnitine is involved in protecting cells from high concentrations of acetyl-CoA in mitochondria by converting it into acyl-carnitine. Overdose of acetyl-CoA inhibits activity of pyruvate dehydrogenase, the most important enzyme in male energy metabolism. This function of L-carnitine improves sperm survival in the ejaculate and increases the total count of sperm in the ejaculate (Matalliotakis and Koumantakis, 2000). Jeulin and Lewin (1996) observe that increase in the number of sperm in the ejaculate after L-carnitine supplementation is caused by the fact that less dead sperm are absorbed in the epididymis. In our case we did not confirmed this hypothesis in our experiment.

Sperm with distal protoplasmic droplets is understood the most frequently occurring morphological sperm abnormality (Lipenský et al., 2010). Čeřovský et al. (2009) reported that after 56 days of L-carnitine supplementation was measured the lowest percentage of morphologically abnormal sperm (18.92\%) and the highest percentage in the control group by the end of the experiment (37.00\%). Jacyno et al. (2007) recorded the statistically significant decrease in the percentage of morphologically abnormal sperm during the experiment-the primary morphological changes decreased by $6.8 \%$ and the secondary morphological changes decreased by $9.3 \%$ $(\mathrm{P}<0.01)$. In our experiment we have established the statistically significant differences between the monitored groups.
The damage of mitochondria is one of the reasons of infertility (Piomboni et al., 2012). During the long-term preservation, there can be high amount of the oxidative compound, which is generated by metabolic activity of sperm cells (Lee et al., 2014). Čeřovský et al. (2009) as well as Yeste et al. (2010) have not reported a statistically significant increase in sperm motility between treated and control group. Barranco et al. (2013) reported different conclusions, namely that during the summer season sperm motility is reduced significantly, compared to the other seasons. In this study, we confirmed, that L-carnitine may protect sperm cells against the potential oxidative damage.

A relatively high dose of L-carnitine in the feed ( $2 \mathrm{~g} /$ boar/day) affects increase of L-carnitine concentration in the epididymis, and thus in the ejaculated plasma and sperm. However, Čeřovský et al. (2009) did not reveal a significant increase of L-carnitine in the seminal plasma. In our experiment, a significant increase of L-carnitine concentration in the ejaculate was established in the experimental group in August.

The greatest changes in ejaculate quality occurred in the boars exposed to a short-term temperature of $30^{\circ} \mathrm{C}$ (continuous for 3 days under laboratory conditions) or after a long-term exposure to the temperatures of $26-29^{\circ} \mathrm{C}$ (Louda et al., 2001). Positive effect of L-carnitine addition can be observed as early as after a week of L-carnitine addition into the ration. However, the highest statistically significant increase of the evaluated indicators was recorded after 4 weeks of L-carnitine supplementation (Jacyno et al., 2007). We have measured daily maximum temperatures up to the $30^{\circ} \mathrm{C}$, so there was a possibility of heat stress, during the experiment.

\section{CONCLUSION}

With respect to the results, we can conclude that the temperatures above $25^{\circ} \mathrm{C}$ can influence quality of boar ejaculate. We have also confirmed the hypothesis, that daily supplementation of L-carnitine in dose 500 $\mathrm{mg} / \mathrm{kg}$ feed mixture can protect sperm from the potentional oxidative stress. In our case supplementation had positive effect on sperm motility and percentage of morphologically abnormal sperm.

Acknowledgments

This project was funded from grants and IP 034/2017.

\section{REFERENCES}

AGARWAL, A. and SAIT, T. M. 2004. Carnitines and male infertility. Reprod. Biomed. Online, 8(4): 376-384.

AITKEN, R., BAKER, M. and SAWYER, D. 2003. Oxidative stress in the male germ line and its role in the etiology of mela in fertility and genetic disease. Reprod. Biomed. Online, 7(1): 65-70.

AITKEN, R. J. 1994. A free-radical theory of male-infertility. Reprod. Fertil. Dev., 6(1): 19-24.

ARRIGONI-MARTELLI, E. and CASO, V.2001. Carnitine protects mitochondria and removes toxic acylsfrom xenobiotics. Drugs Exp. Clin. Res., 27(1): 27-49.

BARRANCO, I., ORTEGA M. D., MARTINEZ-ALBORCIA, M. J., VAZQUEZ, J. M., MARTINEZ, E. A. and ROCA, J. 2013. Season of ejaculate collection influences the freezability of boar spermatozoa. Cryobiology, 67(3): 299-304.

BAUMGARTNER, M. 1998. Boars react positively to L-carnitine supplements. Int. Pig. Topics, 13: 22. 
ČEŘOVSKÝ, J., FRYDRICHOVÁ, S., LUSTYKOVÁ, A., LIPENSKÝ, J. and ROZKOT, M. 2009. Semen characteristics of boar receiving control diet and control diet supplemented with L-Carnitine. Czech. J. Anim. Sci., 54(9): 417-425.

CIBULKA R. 2005. Metabolic effects of carnitine and its role in medicine. Clin. Endocrinol. Metab., 13(1): 24-28.

GADD, J. 2011. Modern pig production technology: a practical guide to profit. New Edition. Nottingham: Nottingham University Press.

HÁJEK, J., ADAM, L., CIPRA, P., ČEŘOVSKÝ, J., ČÍTEK, V., JELÍNEK, T., KRÁLÍK, Z., KRÁTKÝ, F., NOVÁK, I., PAVLÍK, J., SMOLÁK, M., STEINHAUSER, L., TOBIŠKOVÁ, J. and VICENOVÁ, M. 1992. Prasata v drobném chovu a na farmách. Praha: APROS.

HANSEN, P. J. 2009. Effects of Heat Stress on Mammalian Reproduction. Philos. Trans. R. Soc. Lond. B. Biol. Sci., 364(1534): 3341-3350.

HOPPEL, C. 2003. The role of carnitine in normal and altered fatty acid metabolism. Curr. Med. Chem., 10: 2495-2505.

HORKÝ, P. 2014. Influence of increased dietary selenium on glutathione peroxidase activity and glutathione concentration in erythrocytes of lactating sows. Ann. Anim. Sci., 14(4): 869-882.

HORKÝ, P., JANČÍKOVÁ, P., SOCHOR, J., HYNEK, D., CHAVIS, G. J., RUTTKAY-NEDECKÝ, B., CERNEI, N., ZİTKA, O., ZEMAN, L., ADAM, V. and KIZEK, R. 2012. Effect of organic and inorganic form of selenium on antioxidant status of breeding boars ejaculate revealed by electrochemistry. Int. J. Electrochem. Sci., 7(10): 9643-9657.

HORKÝ, P., SKLÁDANKA, J., NEVRKLA, P. and SLÁMA, P. 2016. Effect of Diet Supplemented with Antioxidants (Selenium, Copper, vitamins E and C) on Antioxidant Status and Ejaculate Quality of Breeding Boars. Ann. Anim. Sci., 16(2): 521-532.

HORKÝ, P., TMEJOVÁ, K., KENŠOVÁ, R., CERNEI, N., KUDR, J., RUTTKAY-NEDECKÝ, B., SAPÁKOVÁ, E., ADAM, V. and KIZEK, R. 2015. Effect of Heat Stress on the Antioxidant Activity of Boar Ejaculate Revealed by Spectroscopic and Electrochemical Methods. Int. J. Electrochem. Sci., 10(8): 6610-6626.

JACYNO, E., KOLODZEJ, A., KAMYCZEK, M., KAWECKA, M., DZIADEK, K. and PETRUSZKA, A. 2007. Effect of L-carnitine supplementation on boar semen quality. Acta. Vet. Brno, 76: 87-102.

JEULIN, C., DACHEUX, J. L. and SOUFIR, J. C. 1994. Uptake and release of free L-carnitine by boar epididymal spermatozoa in vitro and subsequent acetylation rate. J. Reprod. Fertil., 100(1): 263-271.

JEULIN, C. and LEWIN, L. M. 1996. Role of free L-carnitine and acetyl-L-carnitine in post-gonadal maturation of mammalian spermatozoa. Hum. Reprod. Update, 2: 87-102.

JEULIN, C., SOUFIR, J. C., MARSON, J., PAQUIGNON, M. and DACHEUX, J. L. 1987. The distribution of carnitine and acetylcarnitine in the epididymis and epididymal spermatozoa of the boar. J. Reprod. Fertil., 79(2): 523-529.

KALAISELVI, C. J. and PANNEERSELVAM, C. 1998. Effect of L-carnitine on the status of lipid peroxidation and antioxidants in ageing rats. J. Nutr. Biochem., 9(10): 575-581.

KNECHT, D., ŚRODOÑ, S. and DUZIŃSKI, K. 2014. The influence of boar breed and season on semen parameters. S. Afr. J. Anim. Sci., 44(1): 1-9.

KUNAVONGRIT, A., SURIYASOMBOON, A., LUNDEHEIM, N., HEARD, T. W. and EINARSSON, S. 2005. Management and sperm production of boars under differing environmental conditions. Theriogenology, 2:657-667.

LEE, Y. J., LEE, S. H., LEE, E., LEE, S. T., CHEONG, H. T., YANG, B. K., LEE, S. and PARK, C. K. 2014. Effects of L-carnitine during the storage of fresh semen in miniature pigs. Reprod. Dev. Biol. 38(4): 171-177.

LIPENSKÝ, J., LUSTYKOVÁ, A. and ČEŘOVSKÝ, J. 2010. Effect of season on boar sperm morphology. Journal of Central European Agriculture, 11(4): 465-468.

LOUDA, F., ČEŘOVSKÝ, J., JEŽKOVÁ, A. and STÁDNÍK, L. 2001. Inseminace hospodárských zvírat se základy biotechnických metod. Praha: ČZU.

LOVERCAMP, K. W., STEWART, K. R., LIN, X. and FLOWERS, W. L. 2013. Effect of dietary selenium on boar sperm quality. Anim. Reprod. Sci., 138: 268-275.

MATALLIOTAKIS, I. and KOUMANTAKIS, E. 2000. L-carnitine levels in the seminal plasma of fertile and infertile men: correlation with sperm quality. Int. J. Fertil. Womens Med., 45(3): 236-240.

MAYA-SORIANO, M. J., TABERNER, E., SABES-ALSINA, M. and LOPEZ-BEJAR, M. 2013. Retinol might stabilize sperm acrosomal membrane in situations of oxidative stress because of high temperatures. Theriogenology, 79(2): 367-373.

PIOMBONI, P., FOCARELLI, R., STENDARDI, A., FERRAMOSCA, A. and ZARA, V. 2012. The role of mitochondria in energy production for human sperm motility. Int. J. Androl., 35(2): 109-124.

SMITAL, J. 2001. Chov a ošetřování pohlavně aktivních kanců. Náš chov, 6: 36-40.

VAZ, F. M. and WANDERS, R. J. 2002. Carnitine biosynthesis in mammals. Biochem. J., 361: 417-429.

VITALI, G., PARENTE, R. and MELOTTI, C. 1995. Carnitine supplementation in human idiopathic asthenospermia: clinical results. Drugs. Exp. Clin. Res., 21(4): 157-159. 
YESTE, M., SANCHO, S., BRIZ, M., PINART, E., BUSSELLEU, E. and BONET, S. 2010. A diet supplemented with L-carnitine improves the sperm quality of Piétrain but not of Duroc and Large White boars when photoperiod and temperature increase. Theriogenology, 73(5): 577-586. 